\title{
IMPOSEX IN THAIS RUSTICA (MOLLUSCA: NEOGASTROPODA) (LAMARK, 1822) AS AN INDICATOR OF ORGANOTIN COMPOUNDS POLLUTION AT MACEIO COAST (NORTHEASTERN BRAZIL)
}

\author{
Edmundo Camillo ${ }^{I *}$; Juliana Quadros ${ }^{I}$; Ítalo Braga de Castro ${ }^{2}$ \& Marcos Fernandez \\ ${ }^{1}$ Universidade do Estado do Rio de Janeiro - UERJ \\ Departamento de Oceanografia \\ (Rua São Francisco Xavier, 524, $4^{\circ}$ andar - sala 4026, Bloco I, \\ Maracanã 20590-900, Rio de Janeiro, RJ, Brasil) \\ ${ }^{2}$ Universidade Federal do Ceará \\ Instituto de Ciências do Mar - LABOMAR - Divisão de Oceanografia Biótica \\ (Av. Abolição, 3207 - Meireles, 60165-081, Fortaleza, CE, Brasil)
}

\begin{abstract}
A B S T R A C T
The use of OTC (organotin compounds) as biocides in naval antifouling paints causes impacts on non-target organisms. One of these impacts is a syndrome called imposex in gastropod molluscs. Imposex is the imposition of male secondary sexual characteristics in female gastropods as result of endocrine disruption. In this preliminary study, imposex was observed in four out of ten sampled stations in Maceió: the city Port (100\% females exhibited imposex), the Marine Emissary $(23 \%$ females exhibited imposex), the Marine Terminal (35\% females exhibited imposex) and Saco da Pedra beach ( $12 \%$ females exhibited imposex). These stations were distributed in a NE-SW orientation from the Port southwards along the coastline, following the general circulation pattern of the area. The low values of VDSI, RPSI and RPLI indicate that Maceió Coast is a less contaminated area, probably because of low shipping activities together with the fact that the sampling zone is an open coastal system and not an enclosed bay. These results suggest that the imposex development in Thais rustica may be used as a biological indicator of OTC pollution.
\end{abstract}

\section{RESUMO}

O uso de COE (compostos orgânicos de estanho) como biocida em tintas antiincrustantes para embarcações causa impactos em organismos não-alvos. Um destes impactos é a síndrome chamada imposex, em moluscos gastrópodos. Imposex é a imposição de caracteres sexuais secundários masculinos em fêmeas de gastrópodos como resultado de desregulação endócrina. Neste estudo preliminar, o imposex foi observado em quatro de dez estações de amostragem em Maceió: o Porto de Maceió (100\% de fêmeas imposexadas), o Emissário Submarino (23\% de fêmeas imposexadas), o Terminal Marítimo (35\% de fêmeas imposexadas) e a praia do Saco da Pedra (12\% de fêmeas imposexadas). Estas estações estão distribuídas no litoral no sentido NE/SW a partir do Porto, seguindo o padrão de circulação local. Os valores relativamente baixos dos índices VDSI, RPSI e RPLI indicam que a costa de Maceió é uma área moderadamente impactada. Isto poderia ser explicado pelo fato da costa não ser um sistema abrigado e pelo pequeno movimento de sua zona portuária. Estes resultados sugerem que o desenvolvimento do imposex em Thais rustica pode ser usado como indicador da poluição por COEs.

Descriptors: Imposex, Organotin compounds, Pollution, Thais rustica, Maceio.

Descritores: Imposex, Compostos organoestânicos, Poluição, Thais rustica, Maceió.

\section{INTRODUCTION}

Organotin compounds such as tributyltin (TBT) and triphenyltin (TPT) have been used as biocides in antifouling paints for ships since the late sixties (Gibbs \& Bryan, 1994; Lau Wong, 1991). The presence of these compounds in the marine

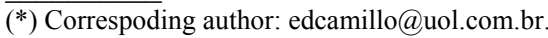

environment has caused impacts on non-target organisms, as shell malformation in bivalve molluscs and endocrine disturbance in gastropods (Alzieu et al., 1986; Smith, 1981).

Smith (1971) described the development of male characteristics in female gastropod molluscs (Nassarius obsoletus), calling this phenomena imposex. This endocrine disruption syndrome is caused by TBT accumulation in these 
marine organisms. The organotin compound TPT also induces imposex in some gastropod species (Thais clavigera, Hung, et al., 2001; Thais gradata, Tan, 1999; Stramonita haemastoma). The use of these compounds as antifoulings is controlled in many countries, and a global ban on organotins in antifoulings was scheduled by IMO (International Maritime Organisation) to be in force by January, 2003 (Hoch, 2001; Fernando et al., 2002). However, the treaty was not ratified by the required number of countries and has not been put into practice yet.

The importance of using gastropods as biological indicators of OTC pollution is derived from the high costs in time and money of chemical analysis, both in water and sediments, and also because imposex is induced by very low TBT concentration $\left(<1\right.$ ng. $\left.\mathrm{L}^{-1}\right)$ (Stroben et al., 1995). Therefore imposex is a useful tool for mapping OTC impacted areas, acting as an important biomarker (Minchin \& Minchin, 1997).

The relationship between imposex and OTC, mainly TBT, was first proved in England by Smith (1981), and many species were listed as indicators of this organotin compounds: Nucella lapillus (Gibbs \& Bryan, 1987), Thais clavigera (Hung et al., 2001), Chicoreus capucinus (Tan, 1999), Thais (Stramonita) haemastoma (Spence et al., 1990; Rilov et al., 2002), Buccinum undatum (Mensink et al., 1997), Lepsiella vinosa (Nias et al., 1993) and others.

Related studies carried out in Brazil are all recent: Guanabara Bay (Fernandez et al., 2002), Arraial do Cabo and Ribeira Bay in the State of Rio de Janeiro; Santos, in the State of São Paulo; Fortaleza (Castro et al., 2000) in the State of Ceará. All Brazilian studies used the gastropod T. (Stramonita) haemastoma as bioindicator.

This work evaluates imposex development in the neogastropod T. rustica in Maceió, capital of the State of Alagoas, where OTC pollution has never been studied. It was done a preliminary survey of possible OTC sources, of the local water circulation pattern and of the distribution of populations of $T$. rustica and T. (Stramonita) haemastoma in the region. This preliminary survey showed that only $T$. rustica has adequate populations for this study, since no individuals of $T$. (Stramonita) haemastoma have ever been found. Species identification was carried out at LABOMAR/UFC. Local currents are found to follow a NE-SW pattern most of the year.

\section{Materials And Methods}

After the preliminary studies, ten sampling zones were selected for the survey along Maceió coast $\left(9^{\circ} 33^{\prime}-9^{\circ} 42^{\prime} \mathrm{S} / 35^{\circ} 38^{\prime}-35^{\circ} 50^{\prime}\right.$ W, Fig. 1). The neogastropod $T$. rustica was chosen as a possible indicator species because of the known TBT sensitivity of the genera (Spence et al., 1990; Bech, 1998) and its broad distribution along the studied coast. The use of this species was also supported by anatomical analogy with $T$. (Stramonita) haemastoma.

These ten sampling zones were selected to study the occurrence of imposex intensity gradients in OTC pollution susceptible areas and in some control areas, where OTC pollution is assumed to be low or absent. The first case included stations 5 (Maceio Port [W]) to 8 (Saco da Pedra beach), where most naval activities were concentrated. The second case included stations 1 (Sereia beach) to 4 (Maceió Port [E]) and 9 (Frances beach) - 10 (B. S. Miguel). The stations 1 to 4 had little boating activities and were located in the opposite direction of local currents when related to the main theoretical source of the area, the Port (W). On the other hand, the stations 9 and 10 were far from the main OTC sources. The type of boating activity was recorded in each station.

Samples of thirty adult $T$. rustica individuals were collected at low tide, during February and March 2002. Specimens were selected by shell size (about 20-30 mm size class) and the presence of marked ribs in the shell edge, as ribs tend to be very pronounced in mature specimens (Spence et al., 1990; Minchin \& Davies, 1999).

A 1:1 solution of $\mathrm{MgCl}_{2} 7 \%$ in distilled water and local seawater was used to narcotize the animals. Shell and penis length of males and imposexed females were measured. The sexual distinction was done by observing of the internal anatomy, identifying the prostate gland in males and the sperm-ingesting gland, the capsule gland and the albumen gland in females. Females that showed male sexual organs were identified as imposexed (Horiguchi et al., 1994).

Imposex was measured using three indices: (1) the VDSI (vas deferens sequence index) that is an increasing masculinization sequence of stages $(0-\mathrm{VI})$, adapted from the Gibbs scale originally proposed to Nucella lapillus, with little alterations to $T$. (Stramonita) haemastoma (Fernandez et al., 2002) (Table 1); (2) the RPSI (relative penis size index): [female mean penis length] ${ }^{3}$ / [male mean penis length] $]^{3} \times 100$ and the (3) RPLI (relative penis length index): [female mean penis length] / [male mean penis length] x 100. These indices compare the bulk of the female penis with that of the male, the first related to volume and the second related to length (Gibbs \& Bryan, 1994; Fioroni et al., 1991; Minchin \& Davies, 1999). Imposex occurrence was calculated from the proportion between imposex female and total female in each sampling station. 


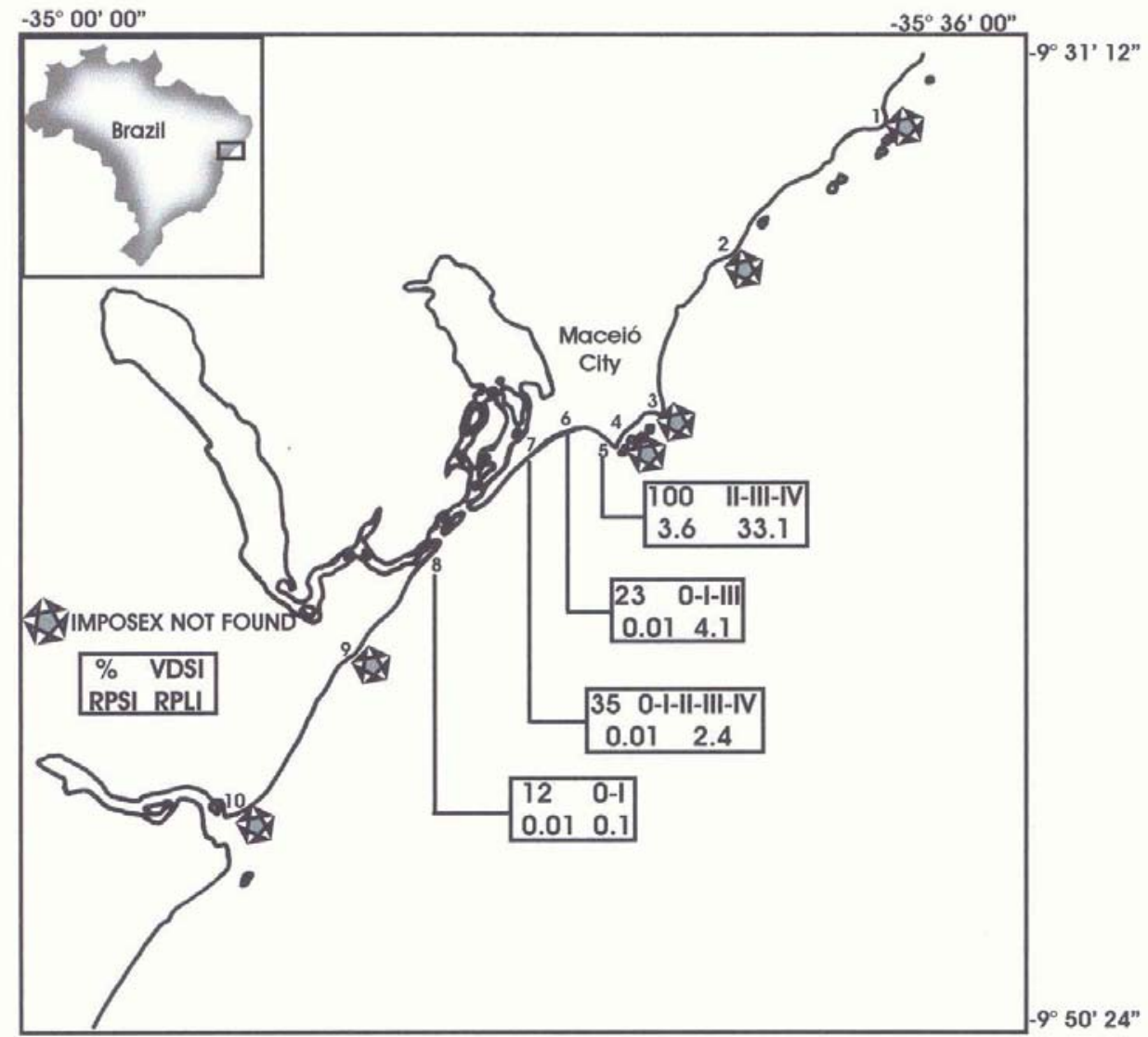

Fig. 1. Study area map showing the location of stations, occurence of imposex, and imposex development indexes VDSI, RPSI, RPLI.

\section{Results}

Four of the ten sampling zones showed imposex occurrence. The highest values indices were found in the western area of Maceió Port (station 5): $100 \%$ of imposex occurrence, VDSI II, III and IV, RPSI 3.6 and RPLI 33.1. Second, station 7 showed $35 \%$ imposex affected females, VDSI 0, I, II, III and IV, RPSI 0.01 and RPLI 2.4. Third, station 6 exhibited $23 \%$ of imposex occurrence, VDSI 0, I and III, RPSI 0.01 and RPLI 4.1. Fourth, station 8, the lowest affected site, presented $12 \%$ of imposex, VDSI 0 and I, RPSI 0.01 and RPLI 0.1. All the other sampling zones showed only healthy females (Fig. 1).

\section{DisCUSSION}

As it can be observed in Figure 1 and Table 2, imposex occurrence was related to shipping activities. The highest values of all indices were observed in stations 5 (Maceio Port [W]) and 7
(Marine Terminal), closer to the ship moorings. The lowest intensities observed at stations 6 (Emissary) and 8 (Saco da Pedra beach), downstream from sources, are characteristic imposex gradients, related to dispersion of compounds from sources. In another study by our group, at Ribeira Bay, in the State of Rio de Janeiro, physical multi-source dispersion modelling showed a very good agreement with imposex intensities in T. (Stramonita) haemastoma. A further confirmation of these observations is the fact that station 4 , in the wave breaker outside the Port, showed no females with imposex even though they were located only a few hundred meters upstream from sources.

The occurrence of imposex is related to the traffic of big ships in stations 5 and 7. The other sampling zones with boating activity, stations 3 and 10 (pleasure boats and fishing), were not considered significant OTC sources since organisms exhibiting imposex were not found. 


\begin{tabular}{cccccccc}
\hline \hline Stage & $\mathbf{0}$ & I & II & III & IV & V & VI \\
\hline Characteristics & $\begin{array}{c}\text { Healthy } \\
\text { female }\end{array}$ & $\begin{array}{c}\text { Presence } \\
\text { of a } \\
\text { pre-penis. }\end{array}$ & $\begin{array}{c}\text { Developed } \\
\text { penis } \\
( \pm 1 \mathrm{~mm})\end{array}$ & $\begin{array}{c}\text { Well developed penis } \\
(>1 \mathrm{~mm}) \text { and/or } \\
\text { incomplete } \\
\text { vas deferens (IVD). }\end{array}$ & $\begin{array}{c}\text { Complete vas } \\
\text { deferens } \\
\text { (CVD). }\end{array}$ & $\begin{array}{c}\text { Vulva blocked } \\
\text { by the vas } \\
\text { deferens tissue. }\end{array}$ & $\begin{array}{c}\text { Aborted capsules in } \\
\text { capsule gland. }\end{array}$ \\
\hline
\end{tabular}

Table 1. The scale used for VDSI evaluation in T. rustica adapted from Gibbs scale.

Table 2. Sampling stations location, mean shell and penis length for each station and type of boating activity. Legend: $\mathbf{S}$ station; Y - yatch; F - fishing; $\mathbf{C}$ - commercial; $\mathbf{N}$ - number of individuals; $\mathbf{M}$ - male; $\mathbf{F}$ - female.

\begin{tabular}{|c|c|c|c|c|c|c|c|}
\hline \multirow[t]{2}{*}{ Stations } & \multirow[t]{2}{*}{ Positions } & \multirow[t]{2}{*}{$\begin{array}{c}\text { Boating } \\
\text { type }\end{array}$} & \multirow[t]{2}{*}{ N (M:F) } & \multicolumn{2}{|c|}{ Shell length (mm) (min-max/mean) } & \multicolumn{2}{|c|}{$\begin{array}{l}\text { Mean penis length } \\
(\mathrm{mm})\end{array}$} \\
\hline & & & & Male & Female & Male & Female \\
\hline Sereia Beach (S1) & S9 $34^{\circ} 00^{\prime \prime} / \mathrm{W} 35^{\circ} 38^{\prime} 45^{\prime \prime}$ & - & $30(14: 16)$ & $22.4-27.1 / 24.4$ & $22.5-29.1 / 25.6$ & 3.9 & 0.0 \\
\hline Cruz das Almas (S2) & S9 $37^{\prime} 31^{\prime \prime} / W 35^{\circ} 41^{\prime} 37^{\prime \prime}$ & - & $30(15: 15)$ & $20.0-25.1 / 22.3$ & $8.8-27.5 / 21.7$ & 6.5 & 0.0 \\
\hline Alagoas Yatch Club (S3) & S9 $39^{\prime} 53^{\prime \prime} / \mathrm{W} 35^{\circ} 41^{\prime} 46^{\prime \prime}$ & $\mathrm{F}$ & $30(12: 18)$ & $23.4-31.4 / 25.5$ & $22.1-28.9 / 24.5$ & 7.0 & 0.0 \\
\hline Maceió Port (E) (S4) & S9 $40^{\prime} 49^{\prime \prime} / \mathrm{W} 35^{\circ} 43^{\prime} 14^{\prime \prime}$ & $\mathrm{F}$ & $30(10: 20)$ & $24.7-28.9 / 27.0$ & $24.1-29.1 / 25.3$ & 6.1 & 0.0 \\
\hline Maceió Port (W) (S5) & S9 $40^{\prime} 37^{\prime \prime} / \mathrm{W} 35^{\circ} 43^{\prime} 25^{\prime \prime}$ & $\mathrm{F}, \mathrm{Y}, \mathrm{C}$ & $30(17: 13)$ & $19.2-26.7 / 22.7$ & $18.6-28.6 / 22.6$ & 6.1 & 0.0 \\
\hline Emissary (S6) & $\mathrm{S} 9^{\circ} 40^{\prime} 35^{\prime \prime} / \mathrm{W} 35^{\circ} 45^{\prime} 07^{\prime \prime}$ & $\mathrm{C}$ & $30(18: 12)$ & $23.4-27.6 / 25.3$ & $23.7-28.4 / 27.5$ & 6.9 & 0.3 \\
\hline Marine Terminal (S7) & S9 $41^{\prime} 10^{\prime \prime} / \mathrm{W} 35^{\circ} 45^{\prime} 50^{\prime \prime}$ & $\mathrm{C}$ & $30(12: 18)$ & $22.4-36.1 / 26.6$ & $21.8-36.2 / 26.7$ & 8.2 & 0.2 \\
\hline Saco da Pedra Beach (S8) & $\mathrm{S} 9^{\circ} 44^{\prime} 53^{\prime \prime} / \mathrm{W} 35^{\circ} 49^{\prime} 22^{\prime \prime}$ & - & $30(14: 16)$ & $22.7-29.3 / 26.8$ & $23.5-35.2 / 28.0$ & 5.8 & 0.1 \\
\hline Francês Beach (S9)) & $\mathrm{S} 9^{\circ} 46^{\prime} 00^{\prime \prime} / \mathrm{W} 35^{\circ} 50^{\prime} 14^{\prime \prime}$ & - & $30(13: 17)$ & $21.2-31.4 / 25.8$ & $23.8-30.0 / 26.4$ & 5.9 & 0.0 \\
\hline B. São Miguel (S10) & $\mathrm{S}^{\circ} 50^{\prime} 42^{\prime \prime} / \mathrm{W} 35^{\circ} 54^{\prime} 23^{\prime \prime}$ & $\mathrm{F}, \mathrm{Y}$ & $30(11: 19)$ & $28.2-35.5 / 31.5$ & $19.6-34.9 / 30.2$ & 7.0 & 0.0 \\
\hline
\end{tabular}

Observed imposex gradients are inversely proportional to the distance and intensity of the sources for each index, as can be seen in Figure 1. The highest imposex values indices in station 5 show Maceió Port, that is visited by about 300 ships/year (Maceió Port Administration, 2001), is the greatest OTC contributor to Maceió Coast. The sheltered coastline configuration favours higher residence-time of polluted waters in this station. The other stations are located on open coasts where greater water exchange controls OTC dispersion (Penchaszadeh et al., 2001). Because of this aspect and also because of less intense shipping activities (120 ships/year) (Maceió Port Administration, 2001) station 7 showed less intense imposex development. From station 5, where imposex was the most intense, to station 9 , where no imposexed females were observed, the distance is $14 \mathrm{~km}$. This observation indicates a localized impact in the area.

According to the present results (Fig. 1), Maceió Coast can be considered a moderately impacted locality, since the VDSI, RPSI and RPLI values are relatively low, when compared to those found in other contamined areas when using this genus: Azores, Portugal (Mean RPSI $=55$; VDSI=IV) (Spence et al.,1990); Israel Coast (Mean RPSI=30; VDSI=IV) (Rilov et al., 2000); Rio de Janeiro, Brazil (highest RPSI 125 and VDSI reaching V-VI inside Guanabara Bay) (Fernandez et al., 2002); Fortaleza, Brazil (Mean RPSI=29; VDSI= IV-V) (Castro et al., 2000). In the other hand, results from a study in Natal with this same species (Castro et al., 2003) have also shown lower indices values. As these works are the first using T. rustica in biological monitoring, and a parallel study with other species has not been possible yet, the relative sensitivity among species was not tested, and this last observation should be viewed with caution. Sensitivity to organotins is different between species (Stroben et al., 1995), thereby, more studies are required to clarify this question.

It could be concluded that $T$. rustica from Alagoas coast is an exhibitor of imposex and a possible new biological indicator for OTC pollution. The organisms exhibited imposex in different intensities, and these intensities could be related to exposure, showing OTC sensitivity.

\section{REFERENCES}

Alzieu, C.; Sanjuan, J.; Delteil, J. P. \& Borel, M. 1986. Tin Contamination in Arcachon Bay: effects on oyster shell anomalies. Mar. Pollut. Bull., 17(11):494-498.

Bech, M. 1998. Imposex and population characteristics of Thais distinguenda as an indicator of organotin contamination along the South East Coast of Phuket Island, Thailand, Phuket Marine Biological Center, Special publication, 18(1):129-138.

Castro, I. B.; Cascon, H. M. \& Fernandez, M. A. 2000. Imposex in Thais haemastoma (Linnaeus, 1767) (Mollusca:Gastropoda), an indication of organotin contamination in Fortaleza municipality coast - Ceará Brazil. Arq. Ciênc. Mar., 33:51-56.

Castro, I. B.; Meirelles, C. A. O.; Matthews-Cascon, H. \& Fernandez, M. A. 2003. Thais (Stramonita) rustica (Lamarck, 1822) (MOLLUSCA: GASTROPODA: THAIDIDAE), bioindicator of contamination by organotin compounds in the coast of Natal city, Rio Grande do Norte state in northeast of Brasil. Braz. J. Oceanogr., 52(2):43-47. 
Fernandez, M. A.; Terra, A. C. M. A. \& Limaverde, A. M. 2000. Tributyltin and the marine environment: the problem of the use of TBT as biocide in Brazil. Maritime Review, 8(2):52-59.

Fernandez. M. A.; Limaverde, A. M.; Castro, I. B.;Terra, A. C. \& Wagener, A. de L.. 2002. Occurrence of imposex in Thais haemastoma: evidences of environmental contamination derived from organotin compounds in Rio de Janeiro and Fortaleza, Brazil. Publ., Hlth. Rep., 18(2):463-476.

Fioroni, P.; Oehlmann, J. \& Stroben, E. 1991. The pseudohermaphoditism os prosobanchs; morfological aspects. Zoollogischer Anz., 286:1-26.

Gibbs, P. E. \& Bryan, G. W. 1994. Biomonitoring of Tributyltin pollution using the imposex response of Neogastropod Molluscs. In: Kees, J. M. \& Kramer eds Biomonitoring of Coastal Waters and Estuaries. Boca Ratón, CRC Press Inc. p. 205-226.

Gibbs, P. E. \& Bryan, G. W. 1987. TBT paints and the demise of the dog-whelk, Nucella lapillus (Gastropoda). Oceans, 4:1482-1487.

Hoch, M. 2001. Organotin compounds in the environment an Overview. Appl. Geochem., 16:719-743.

Horiguchi, T.; Shiraishi, H.; Shimizu, M. \& Morita, M. 1994. Imposex and organotin compounds in Thais clavigera T. bronni in Japan. J. mar. biol. Ass. U.K., 74:651-669.

Hung, T. C.; Hsu, W. K.; Mang, P. J.; Chuang, A. 2001. Organotins and imposex in the rock shell, Thais clavigera, from oyster mariculture ares in Taiwan. Environ. Pollut. 112:145-152.

Lau Wong, M. M. 1991. Tributyltin antifoulings: a threater to the Hong Kong marine environment. Archs. environ. Contamin. Toxicol., 20:299-304.

MACEIÓ. Companhia Docas. Maceió Port Administration. Statistical Bulletin-2001: base year 2001. Maceió, 2001. 1 disk $3 \frac{1}{2}$.

Mensink, B. P.; Van Hattum, B.; Ten Hallers-Tjabbes, C. C.; Everaarts, J. M.; Kralt, H.; Vethaak, A. D. \& Boon, J. P. 1997. Tributyltin causes imposex in the common whelk, Buccinum undatum - mechanism and occurrence. Netherlands Institute for Sea Research (NIOZ), Texel, Netherlands.

Minchin, A. \& Minchin, D. 1997. Dispersal of tbt from a fishing port determined using the dogwhelk nucella lapillus as an indicator. Environ. Sci. Technol., 18:12251234.

Minchin, A. \& Davies, I. M. 1999. Effect of freezing on the length of the penis in Nucella lapillus. J. environ. Monit., 1:203-205.
Nias, D. J.; Mckillup, S. C. \& Edyvane, K. S. 1993. Imposex in Lepsiella vinosa From Southern Australia. Mar. Pollut. Bull., 26(7):380-384.

Penchaszadeh, P. E.; Averbuj, A. \& Cledón, M. 2001. Imposex in Gastropods from Argentina (South-Western Atlantic). Mar. Pollut. Bull., 42(9):790-791.

Rilov, G.; Gasith, A.; Evans, S. M. \& Benayahu, Y. 2002. Unregulated use of TBT-based antifouling paints in Israel (Estern Mediterranean): High contamination an imposex levels in two species of marine Gastropods. Mar. Ecol. Prog. Ser., 192: 229-238.

Smith, B. S. 1971. Sexuality in American Mud Snail, Nassarius obsoletus. Proc. Malacol. Soc. Lond., 39:377378.

Smith, B. S. 1981. Tributyltin compounds induced male characteristics on female Mud Snails (Nassarius obsoletus=Ilyanassa obsoleta). J. appl. Toxicol., 1(3): 141-144.

Spence, S. K.; Hawkins, S. J. \& Santos, R. S. 1990.The mollusc Thais haemastoma - an exhibitor of imposex and potential biological indicator of tributyltin pollution. Mar. Ecol., 11:147-156.

Stroben, E.; Schulte-Oehlmann, U.; Fioroni, P. \& Oehlmann, J. 1995. A c omparative method for easy assessment of coastal TBT pollution by the degree of imposex in prosobranch species. Haliotis, 24:1-12.

Tan, K. S. 1999. Imposex in Thais gradata and Chicoreus capucinus (Mollusca, Neogastropoda, Muricidae) from the straits of Johor: a case study using penis length, area and weight as measures of imposex severity. Mar. Pollut. Bull. 39(1-12):295-303. 